\title{
ANALISIS FAKTOR-FAKTOR PENYEBAB KESULITAN BELAJAR PADA BIDANG STUDI AKUNTANSI
}

\author{
M. Saipul Watoni \\ STIT Palapa Nusantara \\ e-mail : saipulwatoni212@gmail.com
}

\begin{abstract}
ABSTRAK
Tujuan penelitian ini adalah untuk mengetahui faktor-faktor penyebab terjadinya kesulitan belajar pada bidang studi akuntansi MA Palapa Nusantara Tahun Pelajaran 2018/2019.

Jenis penelitian ini adalah Penelitian Deskriptif. Teknik pengumpulan data adalah angket (Quesioner), lembar observasi dan dokumentasi. Teknik analisa data dengan teknik analisis persentasional tiap kategori angket.

Berdasarkan hasil analisis data dapat disimpulkan bahwa ada faktor-faktor penyebab kesulitan belajar pada bidang studi Akuntansi siswa kelas XI Jursan IPS MA Palapa Nusantara Tahun Pelajaran 2018/2019. faktor-faktor yang menyebabkan kesulitan belajar siswa pada bidang studi akuntansi adalah faktor internal dan eksternal. Faktor internal antara lain kemampuan daya tangkap (intelegensi) siswa yang berbeda, kurang minat siswa dalam mengulangi kembali materi yang telah dipelajari, faktor kelelahan. Faktor eksternal antara lain kurangnya metode yang diajarkan oleh guru saat mengajar, Jam pelajaran yang relatif kurang, fasilitas kurang memadai, kurang motivasi orang tua, dan faktor lingkungan dan masyarakat.
\end{abstract}

Kata kunci: faktor-faktor Penyebab kesulitan belajar. 


\section{PENDAHULUAN}

\section{A. Latar Belakang}

Proses belajar mengjar merupakan kegiatan yang paling pokok di sekolah, ini berarti bahwa berhasil tidaknya pencapaian tujuan pendidikan banyak tergantung pada bagaimana proses belajar yang dialami oleh siswa sebagai anak didik khususnya pada proses belajar mengajar seseorang tidak pernah lepas dari bermacam hal yang dipengaruhinya, baik itu datang dari dalam individu maupun dari luar individu itu sendiri. Karena dalam menjalankan proses belajar mengajar seseorang akan senantiasa berinteraksi dengan lingkungan sekitarnya. Dimana interaksi tersebut dapat membawa pengaruh yang positif dan negatif pada proses belajar mengajar siswa.

Dalam hal ini pengaruh positif dan negatif tersebut akan mempengaruhi tujuan pendidikan yang ingin dicapai dalam proses belajar mengajar. Pengaruh positif itu yang diharapkan, karena akan dapat mendorong siswa untuk belajar dengan baik guna mencapai tujuan pendidikan. Sedangkan pengaruh negatif akan menjadi penghambat bagi siswa dalam mencapai tujuan pendidikan atau dengan kata lain siswa akan mengalami kesulitan dalam belajar. Dalam pencapaian prestasi belajar, siswa tidak terlepas dari masalah dan tingkat kesulitan yang dihadapi masing-masing siswa/masing-masing sekolah berbeda-beda. Masalahmasalah dan tingkat kesulitan ini yang pada akhirnya akan berpengaruh terhadap pencapaian tujuan pengajaran yang selanjutnya mempengaruhi prestasi belajar siswa.

Setiap siswa pada prinsipnya tentu berhak memperoleh peluang untuk mencapai prestasi belajar yang memuaskan, namun dari kenyataan sehari-hari tampak jelas bahwa siswa itu memiliki perbedaan dalam kemampuan intelektual, kemampuan fisik, latar belakang keluarga, kebersamaan, dan pendekatan belajar yang terkadang sangat mencolok antara siswa yang satu dengan yang lainnya.

Sementara itu, penyelenggaraan pendidikan di sekolah-sekolah pada umumnya hanya ditujukan kepada para siswa yang berkemampuan rata-rata, sehingga siswa yang berkemampuan kurang jadi terabaikan. Dengan demikian, 
siswa yang berkategori di luar rata-rata itu (sangat pintar dan sangat bodoh) tidak mendapat kesempatan yang memadai untuk berkembang sesuai dengan kepestiannya. Dari sini timbul apa yang disebut kesulitan belajar (learning difficult) yang tidak hanya menimpa siswa berkemampuan rendah saja, tetapi juga dialami oleh siswa yang berkemampuan rata-rata (normal) disebabkan oleh faktorfaktor tertentu yang menghambat tercapainya prestasi akademik yang sesuai dengan harapan (Muhibbin Syah, $2007: 122){ }^{1}$

Secara garis besar faktor-faktor penyebab timbulnya kesulitan belajar terdiri dari dua macam, yaitu faktor intern dan faktor ekstern. Faktor intern siswa, yakni hal-hal/keadaan-keadaan yang muncul dari dalam diri siswa, seperti intelegensi, labilnya emosi, sikap, terganggunya alat-alat indera penglihatan dan pendengaran. Sedangkan faktor ekstern siswa, yakni hal-hal/keadaan-keadaan yang datang dari luar diri siswa, seperti lingkungan keluarga, masyarakat, dan sekolah.

Dengan adanya beberapa faktor yang menyebabkan kesulitan belajar siswa yang dapat menghambat tercapainya tujuan belajar, maka peneliti tertarik untuk melakukan penlitian dengan judul Analisis faktor-faktor penyebab kesulitan belajar pada bidang studi akuntansi.

\section{KAJIAN TEORI}

\section{Pengertian Analisis dan Konsep Kesulitan Belajar}

a. Pengertian Analisis

Menurut Mudjiono analisis adalah suatu butir soal yang dapat dilakukan secara kuantitatif dan kualitatif. Analisis secara kualitatif menguji tingkat keberhasilan suatu soal secara logis dan rasional. Sedangkan secara kuantitatif menguji tingkat keberhasilan tes melalui teknik statistik (Mudjiono, 2005:62). ${ }^{2}$

\footnotetext{
${ }^{1}$ Syah Muhibbin. 2007. Psikologi Belajar. Jakarta: RajaGrafindo Persada. Hal 122

${ }^{2}$ Mudjiono. 2005. Tes Hasil Belajar. Jakarta: Bumi Aksara. Hal 62
} 
Sedangkan menurut Ansori, analisis adalah kegiatan yang dilakukan untuk menelaah suatu objek, diuraikan menjadi bagian-bagian dan mencermati unsurunsurnya. Ketika berbagai unsur yang diuraikan tersebut ditemukan kesamaan esensial dan kemudian disatukan (Ansori, 2007:134). ${ }^{3}$

b. Konsep Kesulitan Belajar

Pengertian Kesulitan Belajar

Pada umumnya kesulitan merupakan suatu kondisi yang tertentu yang ditandai dengan adanya hambatan dalam kegiatan mencapai tujuan sehingga memerlukan usaha yang lebih keras lagi untuk dapat mengatasinya. Berdasarkan pengertian kesulitan belajar tersebut. Kesulitan belajar dapat diartikan sebagai suatu kondisi dalam proses belajar yang ditandai oleh adanya hambatan-hambatan tertentu dalam mencapai hasil belajar (Fakhruddin, 2007:25). ${ }^{4}$

Sedangkan Dalyono (1997:229) manjelaskan bahwa kesulitan balajar merupakan keadaan dimana anak didik tidak dapat belajar sebagaimana mestinya. 3 Sementara Zainal (2002:62) mengatakan bahwa ada dua faktor yang menghambat kesullitan belajar, yaitu:

a. Faktor indogen Yaitu faktor yang datang dari diri siswa itu sendiri, meliputi: Faktor biologis, yaitu faktor yang berhubungan dengan jasmaniah. Misalnya kesehatan dan cacat badan dan Faktor psikologis, yaitu faktor yang berhubungan dengan rohaniah, meliputi intelegensi, perhatian, minat, bakat, dan emosi.

b. Faktor eksogen Yaitu faktor yang datang dari luar individu, meliputi: Faktor keluarga, yaitu orang tua, suasana rumah, dan ekonomi keluarga dan Lingkungan sekolah, meliputi: Cara penyajian pelajaran yang kurang baik, Hubungan guru dengan siswa kurang harmonis, Hubungan antara siswa dengan siswa kurang menyenangkan, Bahan pelajaran yang terlalu tinggi di

\footnotetext{
${ }^{3}$ Ansori Muhammad. 2007. Penelitian Tindakan Kelas. Bandung: Wacana Prima.Hal : 134

${ }^{4}$ Fakhruddin, 2007. Pengajaran Remidial dan Pengayaan. Malang: Bayumedia Publishing. Hal : 25

${ }^{3}$ Dalyono. 1997. Psikologi Pendidikan. Jakarta: Rineka Cipta. Hal : 229
} 
atas ukuran normal kemampuan siswa, Alat-alat belajar di sekolah yang serba tidak lengkap, Waktu belajar tidak efektif. Lingkungan masyarakat, meliputi: Media massa, seperti bioskop, radio, televisi, majalah, surat kabar, dan sebagainya, Teman bergaul yang memberikan pengaruh yang tidak baik, Adanya kegiatan dalam masyarakat, misalanya adanya tugas-tugas organisasi, belajar pencak silat, belajar menari, dan lainnya, Corak kehidupan tetangga yang berbeda-beda. ${ }^{5}$

\section{Pengertian Belajar}

Belajar adalah sebagai suatu bentuk pertumbuhan atau perubahan dalam diri seseorang yang dinyatakan dalam cara-cara bertingkah laku yang baru berkat pengalaman dan latihan (Zainal, 2002:62). ${ }^{6}$

\section{a. Prinsip-prinsip Belajar}

Prinsip-prinsip belajar adalah "hal-hal yang sangat penting yang harus ada dalam suatu proses belajar dan pembelajaran" (Darsono, 2007:26). Menurut Zainal (2002:44-45) terdapat beberapa prinsip belajar yaitu :

a. Belajar harus bertujuan dan terarah. Tujuan akan menuntunya dalam belajar untuk mencapai harapan-harpannya.

b. Belajar memerlukan bimbingan, baik bimbingan dari guru atau buku pelajaran.

c. Belajar memerlukan pemahaman atas hal-hal yang dipelajari sehingga diperoleh pengertian-pengertian.

d. Belajar memerlukan latihan dan ulangan agar materi pelajaran yang telah dipelajari dapat dikuasai.

e. Belajar adalah suatu proses aktif dimana terjadi saling pengaruh secara dinamis antara murid dengan lingkungannya.

f. Belajar harus disertai keinginan dan kemauan yang kuat untuk mencapai tujuan.

\footnotetext{
${ }^{5}$ Aqib Zainal. 2002. Profesionalisme Guru dalam Pembelajaran. Surabaya: Insan Cendikia. Hal : 62

${ }^{6}$ Darsono, Max. 2007. Belajar dan Pembelajaran. Semarang: IKIP Semarang Hal: 26
} 
b. Belajar dikatakan berhasil apabila telah sanggup menerapkan ke dalam bidang praktek sendiri-sendiri.

\section{METODE PENELITIAN}

\section{A. Jenis Penelitian}

Jenis penelitian yang digunakan dalam penelitian ini adalah penelitian deskriptif, dengan pendekatan kuantitatif yaitu suatu bentuk metode penelitian yang dipergunakan untuk meneliti suatu sel, kondisi dan variabel tentang suatu objek kemudian membuat analisis dan gambaran secara sistematis, faktual dan cermat tentang objek yang diteliti (Nazir, 2008:63) ${ }^{7}$ Penggunaan metode deskriptif dalam penelitian ini dimaksudkan untuk menggambarkan, membuat suatu analisis sitematis faktual, dan cermat tentang analisis faktor-faktor penyebab kesulitan belajar pada bidang studi Akuntansi kelas XI di MA PALAPA NUSANTARA Tahun Pelajaran 2018/2019.

\section{B. Populasi dan Sampel Penelitian}

\section{Populasi}

Dalam penelitian ini yang dijadikan populasi adalah seluruh siswa kelas XI MA PALAPA NUSANTARA sebanyak 120 orang yang terdiri dari 3 kelas, yaitu Kelas XI IPS ${ }_{1}$ sebanyak 40 orang, kelas XI IPS 2 : 40 orang, dan kelas XI IPS $_{3}: 40$ orang.

\section{Sampel}

Sampel dalam penelitian ini adalah 30 Siswa yang diambil dari kelas XI IPS $_{1}$ sebanyak 10 orang, kelas XI IPS 2 sebanyak 10 orang, dan kelas XI IPS 3 sebanyak 10 orang.

\section{Instrumen Penelitian}

Instrumen penelitian dalam penelitian berupa angket, tes, skala bertingkat, pedoman wawancara, observasi, dan chek-lisht.

\footnotetext{
${ }^{7}$ Nazir Moh. 2008. Metode Penelitian. Jakarta: Ghalia Indonesia, Hal :63
} 


\section{Teknik Pengumpulan Data}

Adapun metode yang digunakan dalam penelitian ini adalah angket. Angket digunakan untuk mendapatkan data yang berisikan daftar pertanyaan tertulis dengan indikator-indikator penyebab kesulitan belajar pada bidang studi akuntansi kelas XI MA PALAPA NUSANTARA.

\section{E. Uji Coba Instrumen Penelitian}
1. Validitas
2. Reliabilitas

\section{F. Teknik Analisis Data}

1. Analisis Statistik dan Non Statistik

Dalam penelitian ini, data yang akan dikumpulkan adalah data yang bersifat kuantitatif yang berupa nilai belajar siswa yang mengalami kesulitan belajar.

\section{Uji Normalitas}

Yang dimaksud dengan uji normalitas sampel atau pengujian normal tidaknya sampel, tidak lain sebenarnya adalah untik mengadakan pengujian terhadap normal tidaknya sebaran data yang akan dianalisis. Persamaan uji normalitas sebagai berikut:

$$
X^{2}=\sum\left[\frac{\left(f_{o}-f_{h}\right)^{2}}{f_{h}}\right]
$$

Keterangan:

$X^{2}=$ Harga Chi-Kuadrat yang dicari

$f_{o}=$ Frekuensi yang ada (frekuensi observasi atau frekuensi sesuai dengan keadaan)

$f_{h}=$ Frekuensi yang diharapkan, sesuai dengan teori.

3. Persentase Tiap Kategori Angket

\footnotetext{
${ }^{8}$ Arikunto Suharsimi 2007 Manajemen Penelitian. Jakarta: Rineka Cipta. Hal :312

${ }^{2}$ Nurkancana, Wayan. 1999. Evaluasi Hasil Belajar. Surabaya: Usaha Nasional. Hal:126
} 
Untuk menentukan persentase tiap kategori angket menggunakan rumus sebagai berikut:

$$
P=\frac{\sum X}{N} \times 100 \% \quad \text { (Nurkancana, 1999:126) }{ }^{2}
$$

Keterangan:

$\mathrm{P} \quad=$ Persentase tiap kategori

$\sum X=$ Jumlah respon masing-masing kategori

$\mathrm{N}$ = Banyak responden

4. Pengujian Hipotesis

Dalam pengujian hipotesis peneliti menggunakan uji signifikansi korelasi product moment dengan rumus sebagai berikut:

$\mathrm{t}=\frac{r \sqrt{n-2}}{\sqrt{1-r^{2}}}$

keterangan

$\mathrm{t}=$ Nilai $\mathrm{t}$ yang dihitung

$\mathrm{r}=$ Nilai product moment

$\mathrm{n}=$ Jumlah responden

Kriterianya: Jika $t_{\text {hitung }}<$ dari $t_{\text {tabel }}$ maka $\mathrm{H}_{\mathrm{o}}$ diterima dan $\mathrm{H}_{\mathrm{a}}$ ditolak dan sebaliknya jika $t_{\text {hitung }}>$ dari $t_{\text {tabel }}$ maka $\mathrm{H}_{\mathrm{a}}$ diterima dan $\mathrm{H}_{\mathrm{o}}$ ditolak.

\section{HASIL PENELITIAN DAN PEMBAHASAN}

\section{A. Hasil Penelitian}

\section{Hasil Uji Coba Instrumen}

a. Validitas

Sebelum instrumen digunakan untuk mengambil data di tempat penelitian maka instrumen tersebut harus diujikan terlebih dahulu untuk menentukan validitasnya. Adapun instrumen penelitian ini diuji dengan validitas item dengan rumus product moment. Yang dimaksudkan untuk mengetahui kevalidan soal 
yang akan dipakai untuk mengambil data dalam penelitian. Adapun kriteria validitas item adalah jika $r_{\text {hitung }}>r_{\text {tabel }}$ maka item tes dikatakan valid dan jika $\mathrm{r}_{\text {hitung }}<\mathrm{r}_{\text {tabel }}$ maka item tes dikatakan tidak valid. Dari hasil analisis yang didapatkan bahwa pada soal angket tentang faktor-faktor yang menyebabkan kesulitas belajar siswa yang terdiri dari 20 butir soal hanya diambil 15 butir soal yang sudah dinyatakan valid

Berdasarkan hasil percobaan tentang faktor-faktor yang menyebabkan kesulitas belajar siswa diperoleh reliabilitas soal $=0,92$

Uji Normalitas Data

Untuk menentukan uji normalitas data dilakukan perhitungan antara lain:

1) Menentukan skor besar dan skor kecil

Skor terbesar : 45

Skor terkecil : 21

2) Menentukan rentangan $(R)$

$\mathrm{R}=45-21=24$

3) Menentukan benyak kelas (BK)

$$
\begin{aligned}
\text { BK } & =1+3,3 \log \mathrm{n} \\
& =1+3,3 \log 30 \\
& =1+3,3.1,477 \\
& =1+4,874 \\
& =5,874=6
\end{aligned}
$$

4) Menentukan panjang kelas (i)

$\mathrm{i}=\mathrm{R} / \mathrm{BK}=24 / 6=4$

5) Perhitungan Uji Normalitas Data Angket

Tabel 1 Perhitungan Uji Normalitas Data Angket

\begin{tabular}{|c|c|c|c|c|c|c|c|}
\hline No & Interval & Fh & fo & fo-fh & $\begin{array}{c}\text { (fo- } \\
\text { fh) }\end{array}$ & $\frac{(f o-f h)^{2}}{f h}$ & Ket \\
\hline 1 & $21-25$ & 2,832 & 5 & 2,168 & 4,70 & 1,66 & Normal \\
2 & $26-30$ & 1,491 & 10 & $-8,509$ & 72,40 & 48,56 & Tidak Normal \\
\hline
\end{tabular}




\begin{tabular}{|c|c|c|c|c|c|c|c|}
\hline 3 & $31-35$ & $-0,369$ & 3 & 3,369 & 11,35 & $-30,76$ & Normal \\
4 & $36-40$ & $-0,63$ & 3 & 3,63 & 13,18 & $-20,92$ & Normal \\
5 & $41-45$ & 3,399 & 9 & 5,601 & 31,37 & 9,23 & Normal \\
6 & $46-50$ & $-1,347$ & 0 & 1,3468 & 1,81 & $-1,35$ & Normal \\
\hline \multicolumn{2}{|c|}{5} & & & & & & 6,43 \\
\hline \multicolumn{2}{|c|}{$S=33,90$} & & & & & & \\
\hline
\end{tabular}

Dengan taraf signifikasi 5\% dan derajad kebebasan $\mathrm{dk}=6-1=5$ diperoleh $x_{\text {hitung }}^{2}=6,43$ dan $x_{\text {tabel }}^{2}$ sebesar 11,070. karena $x_{\text {hitung }}^{2}<x_{\text {tabel }}^{2}$ maka data tersebut berdistribusi normal.

a. Menentukan Persentase Tiap Kategori Angket

Analaisis hasil tiap kategori angket sebagai berikut.

1) Faktor yang bersumber dari peserta didik yaitu IQ (Intelengensi), minat (kemauan) dan kesehatan.

a) Kategori Ya : sebanyak 21 orang dengan persentasional $140 \%$.

b) Kadang-kadang: Yang memilih kategori Kadang-kadang sebanyak 7 orang dengan persentasional $46,67 \%$.

c) Kategori Tidak : Yang memilih kategori Tidak sebanyak 2 orang dengan persentasional $13,33 \%$.

2) Faktor sekolah yaitu guru, saran-prasaran dan kurukulum

a) Kategori Ya : Yang memilih kategori Ya sebanyak 23 orang dengan persentasional 153,33\%. 
b) Kadang-kadang : Yang memilih kategori Kadang-kadang sebanyak 4 orang dengan persentasional 26,67\%.

c) Kategori Tidak : Yang memilih kategori Tidak sebanyak 3 orang dengan persentasional $20 \%$.

3) Faktor keluarga yaitu orang tua

a) Kategori Ya : Yang memilih kategori Ya sebanyak 19 orang dengan persentasional $126,67 \%$.

b) Kadang-kadang : Yang memilih kategori Kadang-kadang sebanyak 7 orang dengan persentasional 46,67\%.

c) Kategori Tidak : Yang memilih kategori Tidak sebanyak 4 orang dengan persentasional $26,67 \%$.

4) Faktor masyarakat yaitu lingkungan tempat tinggal peserta didik.

a) Kategori Ya : Yang memilih kategori Ya sebanyak 23 orang dengan persentasional $153,33 \%$.

b) Kadang-kadang : Yang memilih kategori Kadang-kadang sebanyak 4 orang dengan persentasional 26,67\%.

c) Kategori Tidak : Yang memilih kategori Tidak sebanyak 3 orang dengan persentasional $20 \%$.

\section{Deskripsi Data}

Penelitian ini merupakan jenis penelitian deskriptif. Penelitian ini dilakukan untuk menggambarkan, membuat suatu analisis sitematis faktual, dan cermat tentang analisis faktor-faktor penyebab kesulitan belajar pada bidang studi Akuntansi kelas XI di MA PALAPA NUSANTARA Tahun Pelajaran 2018/2019.

3. Berdasarkan hasil angket yang disebarkan pada 30 siswa tentang faktorfaktor penyebab kesulitan belajar pada bidang studi Akuntansi memperoleh nilai rata-rata sebesar 33,90 dan nilai standar deviasi 7,62. dari hasil rata-rata angket terletak pada kategori baik.

\section{Uji Hipotesis}

Dalam pengujian hipotesis dalam penelitian ini menggunakan persamaan Uji-t korelasi product moment. Dari hasil analisis diperoleh Hipotesis yang ditetapkan dalam penelitian ini sebagai berikut: 
$H_{a}$ : Ada faktor-faktor penyebab kesulitan belajar pada bidang studi Akuntansi siswa kelas XI Jurusan IPS MA PALAPA NUSANTARA Tahun Pelajaran 2018/2019.

$H_{o}$ : Tidak ada faktor-faktor penyebab kesulitan belajar pada bidang studi Akuntansi siswa kelas XI Jurusan IPS MA PALAPA NUSANTARA Tahun Pelajaran 2018/2019.

Berdasarkan hasil analisis faktor-faktor penyebab kesulitan belajar pada bidang studi Akuntansi diperoleh $t_{h i t}=17,929$. Berdasarkan kriteria uji hipotesis antara lain: jika $t_{\text {hit }}<$ dari $t_{\text {tab }}$ maka $\mathrm{H}_{\mathrm{o}}$ diterima dan $\mathrm{H}_{\mathrm{a}}$ ditolak dan jika jika $\mathrm{t}_{\text {hit }}>$ dari $\mathrm{t}_{\text {tab }}$ atau 17,929 > 1,729, maka $\mathrm{H}_{\mathrm{o}}$ ditolak dan $\mathrm{H}_{\mathrm{a}}$ diterima. Yang menandakan bahwa ada faktor-faktor penyebab kesulitan belajar pada bidang studi Akuntansi siswa kelas XI Jurusan IPS MA PALAPA NUSANTARA Tahun Pelajaran 2018/2019.

\section{PEMBAHASAN}

\section{A. Pembahasan}

Dari hasil penelitian menunjukan bahwa ada faktor-faktor penyebab kesulitan belajar pada bidang studi Akuntansi siswa kelas XI Jurusan IPS MA PALAPA NUSANTARA Tahun Pelajaran 2018/2019. Hasil perhitungan mencari persentasional tiap kategori angket yang mendapatkan persentasional terbanyak pada kategori Ya dengan jumlah siswa sebanyak 23 orang dengan nilai persentasional sebesar $76,67 \%$.

Siswa yang memilih jawaban Ya memiliki faktor yang menyebabkan kesulitan belajar pada mata pelajaran akuntansi. Faktor-faktor yang menyebabkan kesulitan belajar siswa pada bidang studi akuntansi kelas XI MA PALAPA NUSANTARA antara lain:

1. Faktor-faktor internal penyebab kesulitan belajar siswa kelas XI di MA PALAPA NUSANTARA

Faktor internal merupakan penyebab timbul dari dalam diri siswa yang bersangkutan dengan menjadikan kondisi pribadi sebagai penyebab tanpa dipengaruhi oleh hal-hal yang berasal di luar psilologisnya. Adapun kenyataan- 
kenyataan objek di lapangan yang menggambarkan dengan jelas tentang faktorfaktor internal sebagai berikut:

a. Kemampuan Daya Tangkap (Intelegensi) Siswa yang Berbeda

Beberapa kendala yang dihadapi guru pada saat berlangsungnya proses belajar mengajar, yaitu disebabkan oleh kemampuan daya tangkap siswa yang berbeda-beda. sehingga siswa ada yang lebih cepat paham dan mengarti materi yang disampaikan dan ada siswa yang lamban dalam menerima materi. Hal ini dapat berpengaruh terhadap prestasi belajar siswa, karena mata pelajaran akuntansi butuh ketelitian yang tinggi, tidak perlu dihafal namun butuh banyak latihan. Sehingga siswa harus banyak perhatian dari guru agar siswa tidak malu dalam menanyakan materi yang belum dipahaminya.

Hal ini sesuai dengan pendapat Slameto, (2007:56) yang mengatakan bahwa intelegensi besar pengaruhnya terhadap kemajuan belajar dalam situasi yang sama. Siswa yang mempunyai tingkat intelegensi tinggi akan lebih berhasil dari siswa yang mempunyai tingkat intelegensi rendah.

b. Kurangnya Minat Siswa dalam Mengulangi Kembali Materi yang Telah Dipelajari

Pada saat diberikan tugas rumah (PR), siswa menjawab seadanya tanpa meneliti/menganalisa soal yang diberikan terlebih dahulu sehingga jawaban siswa belum begitu sesuai dengan perintah soal, karena siswa kurang berminat dan jarang mengulangi materi yang sudah disampaikan guru di luar jam pelajaran. Pada dasarnya mata pelajaran akuntansi tidak bisa dihadapi dengan begitu saja tanpa mengulangi kembali dengan banyak latihan di luar jam pelajaran, sehingga tidak akan mengalami kesulitan dalam menjawab tugas yang diberikan untuk dikerjakan di luar jam pelajaran.

c. Faktor Kelelahan

Kondisi siswa kelas XI MA PALAPA NUSANTARA mengalami kelelahan belajar Akuntansi dan yang terjadi adalah penyerapan terhadap materi yang sedang dipelajari tidak begitu optimal. Artinya siswa sukar untuk berkonsentrasi dan berpikir karena waktu belajarnya di siang hari yang seharusnya 
waktu yang disediakan untuk mata pelajaran akuntansi adalah pada pagi hari atau jam pertama pelajaran.

Pada saat jam pelajaran akuntansi diberikan kepada siswa ternyata mereka sudah tidak berminat dan tidak bersemangat dalam belajar karena waktu belajarnya yang sudah terlalu siang. Dalam belajar akuntansi dibutuhkan semangat yang tinggi dengan suasana belajar fresh, karena itu sangat berpengaruh terhadap prestasi belajar siswa.

2. Faktor-faktor eksternal penyebab kesulitan belajar akuntansi siswa kelas XI di MA PALAPA NUSANTARA

Faktor eksternal sebagai penyebab kesulitan belajar akuntansi siswa kelas XI di MA PALAPA NUSANTARA ini merupakan faktor yang berasal dari luar pribadi siswa, yaitu:

a. Kurangnya Metode yang Diterapkan oleh Guru Saat Mengajar (Guru Kurang Profesional)

Guru memegang peranan yang penting dalam menentukan keberhasilan dalam proses belajar mengajar. Guru dituntut untuk memiliki kemampuan yang tinggi dalam mengajarkan anak didiknya, sebab guru tidak hanya berperan sebagai pendidik, akan tetapi guru juga berperan sebagai mediator yang juga menentukn kualitas pendidikan. Metode mengajar bagi guru sangat menentukan apaka materi itu akan menarik untuk dipelajari sehingga kalau seorang pendidik menyajikan materi dengan cara monoton, maka siswa akan merasa bosan dan lama kelamaan siswa akan hilang konsentrasi belajar sehingga dapat berpengaruh terhadap prestasi belajar.

b. Jam Pelajaran yang Relatif Kurang (Waktu Belajar yang Efektif)

Jam pelajaran akuntansi dilakukan sebanyak 2 jam pelajaran dalam seminggu. Ini merupakan waktu yang sangat sedikit dalam membahas materi yang sudah direncanakan, sementara materi sangat banyak yang harus diselesaikan apalagi dalam mempelajari akuntansi membutuhkan ketelitian dan waktu yang banyak untuk latihan, sehingga dengan waktu yang sedikit, maka guru berusaha untuk mengejar dan menyelesaikan materi materi dengan tepat waktu padahal dapat berpengaruh terhadap proses belajar mengajar yang tidak efektif. 
c. Fasilitas Belajar yang Kurang Memadai

Di MA PALAPA NUSANTARA keberadaan perpustakaan yang menyediakan buku-buku akuntansi kerung lengkap. Berdasarkan hasil observasi yang peneliti lakukan bahwa koleksi buku-buku pelajaran akutansi sangat sedikit tidak sesuai dengan jumlah siswa yang akan memakainya, sehingga tidak memungkinkan siswa akan dapat belajar hanya dengan membaca saja di perpustakaan, karena mereka butuh untuk pinjam dan dipelajari di rumahnya. Padahal dengan tersedianya buku yang lengkap akan membuat siswa lebih semangat untuk belajar baik dengan memanfaatkan perpustakan maupun dengan meminjam buku untuk dipelajari di rumah. Bahkan dari realita yang terjadi di lokasi penelitian, jumlah siswa yang berkunjung ke perpustakaan sangat minim disebabkan karena buku yang kurang lengkap.

\section{d. Kurangnya Motivasi Orang Tua}

Berdasarkan hasil angket yang peneliti lakukan terhadap siswa kelas XI dapat diketahui bahwa siswa MA PALAPA NUSANTARA rata-rata berasal dari kelurga yang kurang mampu dan tidak terpelajar. Sehingga siswa kurang mempunyai waktu luang untuk belajar di rumah, karena waktunya digunakan untuk bekerja membantu orang tua memenuhi kebutuhan hidup sehari-hari dan kurangnya perhatian pengawasan orang tua terhadap perkembangan anaknya dalam belajar.

Kurangnya perhatian, dorongan, dan tanggung jawab orang tua terhadap kegiatan belajar anaknya setidaknya dilatar belakangi oleh faktor pendidikan, ekonomi orang tua serta faktor sosial budaya masyarakat sekitarnya. Orang tua seharusnya memberikan motivasi yang tinggi terhadap anak sehingga anak tersebut merasa diperhatikan oleh orang tuanya karena bagaimanapun juga hal-hal tersebut sangat berpengaruh terhadap belajar anaknya.

\section{e. Faktor Lingkungan Masyarakat}

Sebagian siswa kelas XI di MA PALAPA NUSANTARA sering tidak masuk sekolah, terutama anak laki-laki yang banyak bergaul dengan anak-anak muda di lingkungan masyarakat setempat. Pergaulan anak-anak muda yang suka meminum minuman keras dan mencuri. Siswa kelas XI yang turut bergabung 
dalam pergaulan anak muda akan menyebabkan efek yang kurang baik pada diri siswa maupun penilaian di mata masyarakat. Siswa akan dijadikan bahan omongan dilingkungan masyarakat. Hal inilah yang menyebabkan siswa sulit untuk belajar.

Hasil perhitungan uji hipotesis dengan menggunakan persamaan product moment mendaptkan hasil yang baik dengan nilai $r_{x y}=0.959$. dan untuk nilai $\mathrm{t}_{\text {hit }}=$ 17,929. Berdasarkan uji hipotesis diperoleh harga $t_{\text {hit }}=17,929$ terletak pada daerah penerimaan $\mathrm{H}_{\mathrm{a}}>\mathrm{t}$ tabel 1,729 sehingga $\mathrm{H}_{\mathrm{o}}$ ditolak dan $\mathrm{H}_{\mathrm{a}}$ diterima. Artinya: Jadi hipotesis yang menyatakan bahwa ada faktor-faktor penyebab kesulitan belajar pada bidang studi Akuntansi siswa kelas XI Jurusan IPS MA PALAPA NUSANTARA Tahun Pelajaran 2018/2019 dapat diterima.

\section{SIMPULAN}

Berdasarkan tujuan dapat disimpulkan bahwa faktor yang mepengaruhi kesulitan belajar siswa antara lain faktor dari diri siswa yaitu intelegensi, minat (kemauan), dan kesehatan. Faktor dari sekolah yaitu guru yang belum menerapkan metode yang tepat, sarana-prasarana dan kurukulum. Faktor dari keluarga yaitu orang tua yang kurang memperhatikan belajar anaknya. Faktor masyarakat yaitu pergaulan siswa dengan masyarakat di tempat tinggalnya. Dari hasil angket diperoleh nilai rata-rata sebesar 33,90 terletak pada kategori baik, hipotesis yang tetapkan oleh peneliti dapat diterima berarti ada faktor-faktor penyebab kesulitan belajar pada bidang studi Akuntansi siswa kelas XI Jurusan IPS MA PALAPA NUSANTARA Tahun Pelajaran 2018/2019. 


\section{DAFTAR PUSTAKA}

Ansori Muhammad. 2007. Penelitian Tindakan Kelas. Bandung: Wacana Prima.

Aqib Zainal. 2002. Profesionalisme Guru dalam Pembelajaran. Surabaya: Insan Cendikia.

Arikunto Suharsimi. 2007. Manajemen Penelitian. Jakarta: Rineka Cipta.

Darsono, Max. 2007. Belajar dan Pembelajaran. Semarang: IKIP Semarang Press.

Dalyono. 1997. Psikologi Pendidikan. Jakarta: Rineka Cipta.

Fakhruddin, 2007. Pengajaran Remidial dan Pengayaan. Malang: Bayumedia Publishing.

Mudjiono. 2005. Tes Hasil Belajar. Jakarta: Bumi Aksara.

Nazir Moh. 2008. Metode Penelitian. Jakarta: Ghalia Indonesia,.

Slameto. 2007. Belajar dan Faktor yang Mempengaruhinya, Jakarta: Rineka Cipta.

Syah Muhibbin. 2007. Psikologi Belajar. Jakarta: RajaGrafindo Persada. 